\title{
Cytokine-induced Expression of a Nitric Oxide Synthase in Rat Renal Tubule Cells
}

Boaz A. Markewitz, * John R. Michael, ${ }^{\star}$ and Donald E. Kohan*

Divisions of Respiratory, Critical Care, and *Occupational Pulmonary Medicine and ${ }^{\ddagger}$ Nephrology, Department of Medicine, Veterans Administration Medical Center and University of Utah School of Medicine, Salt Lake City, Utah 84132

\begin{abstract}
Nitric oxide (NO') has been implicated in the regulation of renal vascular tone and tubular sodium transport. While the endothelial cell is a well known source of $\mathrm{NO}^{\circ}$, recent studies suggest that tubular epithelial cells may constitutively generate $\mathrm{NO}^{\circ}$. An inducible isoform of nitric oxide synthase which produces far greater quantities of $\mathrm{NO}^{\circ}$ exists in some cell types. We sought to determine whether kidney epithelial cells exposed to cytokines could express an inducible nitric oxide synthase. Primary cultures of rat proximal tubule and inner medullary collecting duct cells generated $\mathrm{NO}^{\circ}$ on exposure to TNF- $\alpha$ and IFN- $\gamma$. NO ${ }^{\circ}$ production by both cell types was inhibited by $N^{\mathbf{G}}$-monomethyl-L-arginine; this inhibition was partially reversed by the addition of excess $L$-arginine. Stimulation of kidney epithelial cells with TNF- $\alpha$ and IFN- $\gamma$ dramatically increased the level of inducible nitric oxide synthase mRNA. In summary, renal proximal tubule and inner medullary collecting duct cells can produce $\mathrm{NO}^{\circ}$ via expression of an inducible isoform of nitric oxide synthase. (J. Clin. Invest. 1993. 91:21382143.) Key words: kidney • proximal tubule • collecting duct • interferon • tumor necrosis factor
\end{abstract}

\section{Introduction}

Nitric oxide $\left(\mathrm{NO}^{\circ}\right)^{1}$ exerts a wide variety of effects on renal blood flow and function (for recent review, see [1]). NO mediates, for example, bradykinin and acetylcholine-induced renal vasodilation $(2,3)$ and inhibits renin release (4). Furthermore, $\mathrm{NO}^{\bullet}$ decreases renal vascular responsiveness to vasoconstrictors $(5,6)$, while inhibitors of $\mathrm{NO}^{\circ}$ synthesis reduce renal blood flow (7). In addition to regulating vascular tone, $\mathrm{NO}^{\circ}$ affects tubule function. Endothelial cell-derived $\mathrm{NO}^{\circ}$, for instance, inhibits sodium transport by cortical collecting tubule cells (8).

The source of $\mathrm{NO}^{\circ}$ in the kidney has been assumed to be endothelial cells. Recent studies, however, indicate that tubule epithelial cells are capable of $\mathrm{NO}^{\circ}$ synthesis $(9,10)$. These studies, however, have only identified $\mathrm{NO}^{\circ}$ production by a constitutive form of nitric oxide synthase $\left(\mathrm{NOS}_{\mathrm{c}}\right)$.

Address correspondence to Donald E. Kohan, M.D., Ph.D., Division of Nephrology, University of Utah School of Medicine, Salt Lake City, UT 84132.

Received for publication 6 August 1992 and in revised form $22 \mathrm{De}$ cember 1992.

1. Abbreviations used in this paper: IFN- $\gamma$, recombinant rat IFN- $\gamma$; IMCD, inner medullary collecting duct; L-NMMA, $N^{\mathrm{G}}$-monomethylL-arginine monoacetate; NO, nitric oxide; $\mathrm{NOS}_{\mathrm{c}}$, constitute form of nitric oxide synthase; $\mathrm{NOS}_{\mathrm{i}}$, inducible nitric oxide synthase; PT, proximal tubule.

J. Clin. Invest.

(c) The American Society for Clinical Investigation, Inc.

Volume 91, May 1993, 2138-2143
Inducible forms of NOS have been found in macrophages, endothelial cells, hepatocytes, Kupffer cells, smooth muscle cells, fibroblasts, and tumor cells (11-21). In these cells, cytokines, immunomodulators, and lipopolysaccharide induce the expression of inducible nitric oxide synthase $\left(\mathrm{NOS}_{\mathrm{i}}\right)(22)$. NOS $_{\mathrm{i}}$ produces $\mathrm{NO}^{\circ}$ for prolonged periods and in concentrations that far exceed the amount produced by the constitutive enzyme (14). Consequently, we conducted the current study to determine if renal epithelial cells contain NOS $_{\mathrm{i}}$. We report that both proximal tubule (PT) and inner medullary collecting duct (IMCD) cells are capable of producing $\mathrm{NO}^{\circ}$ via induction of NOS .

\section{Methods}

\section{Reagents}

Recombinant human TNF- $\alpha$ was purchased from Genzyme Corp. (Cambridge, MA); recombinant rat interferon- $\gamma$ (IFN- $\gamma$ ), Moloney leukemia virus reverse transcriptase, DMEM, Ham's F-12 media, RPMI 1640, FBS, and bovine calf serum from Gibco Laboratories (Grand Island, NY); penicillin-streptomycin solution from Irvine Scientific (Santa Ana, CA); $N^{\mathrm{G}}$-monomethyl-L-arginine monoacetate (LNMMA) from Chem-Biochem Research (Salt Lake City, UT); glacial acetic acid, formic acid, chloroform, and $\mathrm{CaCl}_{2}$ from Mallinckrodt Specialty Chemicals (Paris, Kentucky); types II and IV collagenase from Worthington Diagnostic Systems (Freehold, NJ); insulin, transferrin, and selenium from Collaborative Research (Bedford, MA); RNAase A and Taq polymerase from Promega Corp. (Madison, WI); random hexamers from Boehringer Mannheim (Indianapolis, IN); dNTP from Perkin-Elmer Cetus (Norwalk, CT); guanidine isothiocyanate from Calbiochem (La Jolla, CA); acrylamide from Aldrich Chemical Co., (Milwaukee, WI); ammonium hydroxide reagent from Braun-KnechtHeimann (Salt Lake City, UT); [ $\left.{ }^{32} \mathrm{P}\right] \mathrm{dCTP}$ from Amersham Corp. (Arlington Heights, IL); liquid scintillation cocktail from Beckman Instruments (Fullerton, CA); BCA protein assay reagent from Pierce Scientific (Rockford, IL); Primaria plates from Becton Dickinson \& Co. (Lincoln Park, NJ); and 96-well assay plates from Costar Corp. (Cambridge, MA). Rabbit anti-human vWf antibody was obtained from Accurate Chemical \& Scientific Co. (Westbury, NY). All other reagents, unless stated otherwise, were purchased from Sigma Chemical Co. (St. Louis, MO).

\section{Cell isolation}

Male Sprague-Dawley rats (Sasco, St. Louis, MO) weighing 150-250 g were used for all studies. The following tubule segments were studied:

(a) IMCD cells were obtained by a modification of the method of Grenier $(23,24)$, as previously described by this laboratory $(25-27)$. Briefly, rat renal papillae were minced and incubated in Krebs solution (145 mM NaCl, $5 \mathrm{mM} \mathrm{KCl}, 1 \mathrm{mM} \mathrm{Na}_{2} \mathrm{HPO}_{4}, 2.5 \mathrm{mM} \mathrm{CaCl}_{2}, 1.8 \mathrm{mM}$ $\mathrm{MgSO}_{4}, 5 \mathrm{mM}$ glucose, and $10 \mathrm{mM}$ Hepes, $\mathrm{pH} 7.3$ ) containing $0.1 \%$ type II collagenase and $0.01 \%$ type I deoxyribonuclease for $1 \mathrm{~h}$ at $37^{\circ} \mathrm{C}$. Distilled water was then added to give an osmolality of $120 \mathrm{mOsm}$, a procedure shown to disrupt all cells except those of the collecting duct (23). The cells were washed in PBS containing $10 \%$ albumin, and suspended in modified medium $\mathrm{K} 1$ (see below).

(b) PT cells were isolated by a modification of the method of Vinay $(28)$, as previously described by this laboratory $(29,30)$. Rat renal cor- 
tex was minced and incubated in a balanced salt solution $(118 \mathrm{mM}$ $\mathrm{NaCl}, 4.7 \mathrm{mM} \mathrm{KCl}, 2.5 \mathrm{mM} \mathrm{CaCl}_{2}, 1.1 \mathrm{mM} \mathrm{KH}_{2} \mathrm{PO}_{4}, 1.2 \mathrm{mM} \mathrm{MgSO}_{4}$, $10 \mathrm{mM}$ glucose, $20 \mathrm{mM}$ Na cyclamate, $10 \mathrm{mM}$ Hepes, $\mathrm{pH}$ 7.3) containing $1 \%$ type II collagenase, $0.01 \%$ type I deoxyribonuclease, and $0.1 \%$ soybean trypsin inhibitor for $45 \mathrm{~min}$ at $37^{\circ} \mathrm{C}$. The suspension was strained over a $1,000-\mu \mathrm{m}$ pore mesh, and the tissue going through the mesh was washed three times in balanced salt solution and once in PBS with $5 \%$ BSA. The cells were centrifuged on a Percoll density gradient ( $50 \%$ final concentration of Percoll in balanced salt solution). The F4 fraction, corresponding to a density of 1.22 , was collected, washed, and suspended in culture media (see below).

\section{Cell culture}

(a) IMCD cells. IMCD cells were suspended in modified media $\mathrm{K} 1$ (50:50 DMEM:Ham's F12 containing $5 \mu \mathrm{g} / \mathrm{ml}$ insulin, $5 \mu \mathrm{g} / \mathrm{ml}$ transferrin, $5 \mathrm{ng} / \mathrm{ml}$ selenium, $50 \mathrm{nM}$ hydrocortisone, and $25 \mathrm{ng} / \mathrm{ml} \mathrm{PGE}_{1}$ ) and plated into 24-well Primaria plates. All studies were performed at confluence, $\sim 4-6 \mathrm{~d}$ after incubation at $37^{\circ} \mathrm{C}$ in a $5 \% \mathrm{CO}_{2}$ environment. As expected, confluent monolayers of IMCD cells increased cAMP in response to $10 \mathrm{nM} A D H$ and increased cGMP in response to $10 \mathrm{nM}$ atrial natriuretic peptide.

(b) PT cells. PT cells were plated into 24-well Primaria plates in media consisting of 50:50 DMEM:Ham's F12 containing $5 \mu \mathrm{g} / \mathrm{ml}$ insulin, $5 \mu \mathrm{g} / \mathrm{ml}$ transferrin, $5 \mathrm{ng} / \mathrm{ml}$ selenium, $50 \mathrm{nM}$ hydrocortisone, and $5 \%$ FBS. All studies were performed at confluence, $\sim 3-5 \mathrm{~d}$ after incubation at $37^{\circ} \mathrm{C}$ in a $5 \% \mathrm{CO}_{2}$ environment. Greater than $95 \%$ of the cells stained positive for alkaline phosphatase, a marker for PT brush border. As anticipated, confluent monolayers of PT cells increased cAMP in response to $100 \mathrm{nM}$ PTH, but not $1 \mu \mathrm{M}$ ADH.

(c) Mesangial cells. Mesangial cells were isolated from rats as previously described (26). Briefly, glomeruli were obtained using 60,100, and 200 mesh sieves, incubated in $750 \mathrm{U} / \mathrm{ml}$ type IV collagenase and $0.01 \%$ type I deoxyribonuclease for $30 \mathrm{~min}$ at $37^{\circ} \mathrm{C}$. Digested glomeruli were washed twice and cultured in RPMI 1640 containing $20 \%$ BCS and insulin $(0.5 \mathrm{U} / \mathrm{ml})$ at $37^{\circ} \mathrm{C}$ in a $5 \% \mathrm{CO}_{2}$ incubator. Cultures were used between passages 5 and 10 .

(d) Macrophages. The peritoneum of Sprague-Dawley rats was lavaged with ice-cold saline. Cells were plated in RPMI $1640+10 \%$ FBS and vigorously washed after $1 \mathrm{~h}$. Lipopolysaccharide $(1 \mu \mathrm{g} / \mathrm{ml})$ was added for $12 \mathrm{~h}$ to half the wells. Cells were studied $48 \mathrm{~h}$ after plating.

\section{Immunofluorescence}

Confluent IMCD and PT cell cultures were examined for the presence of endothelial cells with anti-Factor VIII-related antigen (vWF) antibody as previously described (27). Briefly, monolayers grown on coverslips were fixed in ice-cold acetone and incubated with $20 \%$ goat serum for $10 \mathrm{~min}$. The cells were then incubated with rabbit anti-human vWF antibody ( $1: 20$ dilution in 20\% goat serum) for $30 \mathrm{~min}$, washed in PBS, and incubated in FITC goat anti-rabbit IgG (1:10 dilution in $20 \%$ goat serum) for $30 \mathrm{~min}$. After final washing in PBS for $15 \mathrm{~min}$, the coverslips were mounted on glass slides and observed for fluorescence using a Zeiss fluorescent microscope. Endothelial cells scraped from the rat aorta were stained in an identical manner and served as positive controls. To exclude contamination with smooth muscle cells or mesangial cells, immunofluorescence for myosin was conducted in a similar manner as previously described (30).

\section{Experimental protocol}

Confluent cultures of PT and IMCD cells were incubated for up to $96 \mathrm{~h}$ at $37^{\circ} \mathrm{C}$ in a $5 \% \mathrm{CO}_{2}$ environment under the following conditions: $(a)$ PT or IMCD media alone (5\% FBS was added to the modified media $\mathrm{K} 1$ for IMCD cells); (b) $150 \mathrm{U} / \mathrm{ml} \mathrm{TNF}-\alpha+500 \mathrm{U} / \mathrm{ml} \mathrm{IFN}-\gamma$ in media (concentrations shown to induce $\mathrm{NO}^{\circ}$ production in another cell line) (31); (c) $150 \mathrm{U} / \mathrm{ml} \mathrm{TNF-} \alpha+500 \mathrm{U} / \mathrm{ml} \mathrm{IFN}-\gamma+0.5 \mathrm{mM} \mathrm{L-NMMA}$; and $(d) 150 \mathrm{U} / \mathrm{ml} \mathrm{TNF}-\alpha+500 \mathrm{U} / \mathrm{ml} \mathrm{IFN}-\gamma+0.5 \mathrm{mM} \mathrm{L}-\mathrm{NMMA}+5$ $\mathrm{mM}$ L-arginine. In another series of experiments, condition $(b)$ above was repeated using $300 \mathrm{U} / \mathrm{ml}$ TNF- $\alpha$.
Determination of nitrite levels. After incubation, aliquots of the supernatants from the above conditions were removed and immediately tested for nitrite $\left(\mathrm{NO}_{2}^{-}\right)$and nitrate $\left(\mathrm{NO}_{3}^{-}\right)$levels (the stable breakdown products of $\mathrm{NO}^{\circ}$ ) (32). $50 \mu \mathrm{l}$ of the conditioned medium from each well was aliquoted in duplicate into a 96-well plate. To this, $100 \mu \mathrm{l}$ of Greiss reagent ( $1 \%$ sulfanilamide in $30 \%$ acetic acid and $0.1 \% \mathrm{~N}-(1-$ naphthyl)ethylenediamine dihydrochloride in $60 \%$ acetic acid in a 1:1 mixture) was added at room temperature. The plates were shaken for $60 \mathrm{~s}$ at 80 rotations per min. The $\mathrm{NO}_{2}^{-}$reacts with the Greiss reagent to form a chromophore $(33,34)$, and its absorbance at $570 \mathrm{~nm}$ was immediately measured in a microplate reader (MR 700; Dynatech Laboratories Inc., Alexandria, VA). The $\mathrm{NO}_{2}^{-}$level was determined by comparing values obtained for samples with a standard curve established by adding known quantities of sodium nitrite to the media used for the experiment (31).

Determination of $\mathrm{NO}_{3}^{-}$levels. $50 \mu \mathrm{l}$ of conditioned media from each well was aliquoted in duplicate into a 96-well plate. To this, $50 \mu \mathrm{l}$ of a mixture containing $1 \mathrm{M}$ Hepes ( $\mathrm{pH}$ 7.25), $2.4 \mathrm{M}$ ammonium formate (pH 7.2), and an Escherichia coli homogenate with nitrate reductase activity (generous gift from Dr. John Hibbs, Jr., University of Utah) was added in a ratio of 1:1:0.05. The plate was incubated for $60 \mathrm{~min}$ at $37^{\circ} \mathrm{C}$. The plate was then centrifuged for $10 \mathrm{~min}$ at $2,000 \mathrm{rpm}$ at $4^{\circ} \mathrm{C}$. $50 \mu$ of the supernatant was then aliquoted into a new 96-well plate and the $\mathrm{NO}_{2}^{-}$level was measured as described above to determine the total $\mathrm{NO}_{2}^{-} / \mathrm{NO}_{3}^{-}$level $(33,35)$. Standards comprised of sodium nitrite in media were put through the same procedure. The previously determined $\mathrm{NO}_{2}^{-}$level was subtracted from the total amount of $\mathrm{NO}_{2}^{-} / \mathrm{NO}_{3}^{-}$to obtain the $\mathrm{NO}_{3}^{-}$level. After extraction in $1 \%$ lauryl sulfate, the protein level in each well was measured using the BCA protein assay reagent as previously described (36).

Isolation of RNA. RNA was obtained from IMCD and PT cells exposed for $96 \mathrm{~h}$ to media alone or media containing $150 \mathrm{U} / \mathrm{ml} \mathrm{TNF}-\alpha$ $+500 \mathrm{U} / \mathrm{ml} \mathrm{IFN}-\gamma$. Confluent monolayers were overlaid with $4 \mathrm{M}$ guanidinium thiocyanate, $1 \% \beta$-mercaptoethanol, and $1 \% \operatorname{sarcosyl}(\mathrm{pH}$ 7.0). The cells were homogenized and $1 / 10$ th volume $2 \mathrm{M} \mathrm{Na}$ acetate added. The RNA was extracted using acid phenol ( $\mathrm{pH} \mathrm{4.0)}$ and chloroform, precipitated in isopropanol, and resuspended in water. Each sample was quantified spectrophotometrically.

Quantitation of $R N A .5 \mu \mathrm{g}$ of total RNA from each sample was reverse transcribed by incubating with $250 \mathrm{pmol}$ random hexamers, 3 $\mathrm{mM} \mathrm{MgCl} 2,400 \mathrm{U}$ murine Moloney leukemia virus reverse transcriptase, $500 \mu \mathrm{M} \mathrm{dNTP}, 0.01 \mathrm{mM}$ dithiothreitol, $75 \mathrm{mM} \mathrm{KCl}$, and $50 \mathrm{mM}$ Tris- $\mathrm{Cl}$ (final $\mathrm{pH} 8.3$, final volume $50 \mu \mathrm{l}$ ) for $1 \mathrm{~h}$ at $37^{\circ} \mathrm{C}$. After incubation, $5 \mu \mathrm{g}$ RNAase A was added for $5 \mathrm{~min}$ at $37^{\circ} \mathrm{C}$, followed by addition of $20 \mu \mathrm{l} 5 \mathrm{M} \mathrm{NaCl}$ and $200 \mu \mathrm{l}$ water. The cDNA was then extracted in phenol ( $\mathrm{pH}$ 7.8) and chloroform, ethanol precipitated, and resuspended in water.

The cDNA was amplified by polymerase chain reaction. Each sample was measured for $\mathrm{NOS}_{\mathrm{i}}$ and $\beta$-actin cDNA in separate tubes using specific primers. The upstream and downstream primers for $\mathrm{NOS}_{i}$ were 5'-GCATGGACCAGTATAA GGCAAGCA-3' and 5'-GCTTCTGGTCGATGTCATGAGCAA-3', respectively. These yielded a single band corresponding to a 222-bp fragment. The sequence for the 222-bp fragment was analyzed by Margaret Robinson in Dr. Ray White's laboratory at the University of Utah using cycle sequencing with fluoresceinated primer ends. Analysis of the sequence revealed that it was identical to position 1693-1915 in mouse macrophage NOS $_{\mathrm{i}} \mathrm{cDNA}$ (37). These primers have $<40 \%$ homology with rat brain $\operatorname{NOS}_{c}$ cDNA $(37,38)$. Furthermore, these primers, if hybridized to rat brain $\mathrm{NOS}_{c}$, would be predicted to yield a 348-bp product after PCR (38). PCR of rat genomic DNA with the primers for $\mathrm{NOS}_{\mathrm{i}}$ yields a 690 -bp product, indicating that this primer set spans an intron.

The upstream and downstream primers for $\beta$-actin were TGGAGAAGAGCTATGAGCTGCCTG and GTGCCACCAGACAGCACTGTGTTG, respectively, which yielded a single band corresponding to a 201-bp cDNA fragment. PCR of rat genomic DNA with the $\beta$-actin primers yields a 289 -bp product which is complementary to position $2499-2788$ in the $\beta$-actin gene, confirming that this primer set spans an 
intron. PCR was performed by incubating $5 \mu \mathrm{l}(\sim 0.5 \mu \mathrm{g})$ of sample cDNA with $50 \mathrm{mM} \mathrm{KCl}, 10 \mathrm{mM}$ Tris-Cl, $.01 \%$ gelatin, $1.5 \mathrm{mM} \mathrm{MgCl}_{2}$, $2.5 \%$ formamide, $2 \mathrm{U}$ Taq polymerase, $200 \mu \mathrm{M} \mathrm{dNTP}, 100 \mathrm{pmol}$ of $\beta$-actin or $\mathrm{NOS}_{\mathrm{i}}$ primers, and $1 \mu \mathrm{Ci}\left[{ }^{32} \mathrm{P}\right] \mathrm{dCTP}$ in $50 \mu \mathrm{l}$ final volume (final $\mathrm{pH} 8.3$ at room temperature). PCR using $\beta$-actin primers was carried out for $20 \mathrm{cycles}\left(15 \mathrm{~s}\right.$ at $94^{\circ} \mathrm{C}, 15 \mathrm{~s}$ at $65^{\circ} \mathrm{C}, 30 \mathrm{~s}$ at $\left.72^{\circ} \mathrm{C}\right)$ using a Perkin-Elmer Cetus 9600 Gene-Amp System. PCR using NOS primers was carried out for 30 cycles under identical conditions. NOS and $\beta$-actin primers were never combined in the same tube. $20 \mu$ lof the final PCR reaction was electrophoresed using an $8 \%$ acrylamide gel in $1 \times$ TBE buffer. Gels were stained with $1 \mu \mathrm{g} / \mathrm{ml}$ ethidium bromide, the bands corresponding to the cDNA product excised, mixed with scintillation cocktail, and counts per minute determined on a beta counter (Beckman Instruments).

NOS $_{\mathrm{i}}$ and $\beta$-actin cDNA obtained from PCR of reverse transcribed RNA were used to generate standard curves. The cDNA was amplified by PCR, the resultant amplified product divided into small fractions that were, in turn, reamplified. The purity of the final product was confirmed by electrophoresis. If a single band of the appropriate size was obtained, the final product was cleaned using Magic PCR Prep (Promega Corp.) to remove the primers. The cleaned product was again electrophoresed to confirm that it contained only the desired cDNA. If pure, the cDNA was quantitated spectrophotometrically. Standard curves for $\beta$-actin or $\mathrm{NOS}_{\mathrm{i}}$ were made by simultaneously amplifying sample cDNA and, in separate tubes, standard cDNA $\left(10^{-1}-10^{-8} \mathrm{ng} /\right.$ tube). Every PCR amplification included a standard curve. All PCR consisted of simultaneous amplification (in separate tubes) of cDNA for $\mathrm{NOS}_{\mathrm{i}}$ and $\beta$-actin. All results are expressed as atograms NOS $_{\mathrm{i}} \mathrm{cDNA} / \mathrm{pg} \beta$-actin cDNA to control for the amount of RNA initially reverse transcribed.

Statistical analysis. Unless otherwise stated, all data points represent the mean of values obtained from eight experiments. Data for $\mathrm{NO}_{2}^{-}$and $\mathrm{NO}_{3}^{-}$production, when involving more than two groups, were analyzed by analysis of variance. All other data, involving only two groups, were analyzed by the unpaired Student's $t$ test. Statistical significance was taken as $P<0.05$. Values are presented as mean \pm standard error of the mean.

\section{Results}

Cell culture. Confluent IMCD and PT monolayers exhibited dome formation characteristic of salt- and water-transporting epithelia. None of the cell cultures exhibited multivacuolated cells characteristic of interstitial cells. Only the typical cobblestone pattern was apparent on light microscopy; no fibroblasts were seen. No IMCD or PT cells phagocytosed serum-treated zymosan particles; in contrast, $96 \%$ of peritoneal macrophages, whether treated with lipopolysaccharide or not, took up three or more particles. Cultures were negative for myosin immunofluorescence; in contrast, cultured mesangial cells were $99 \%$ positive. Both cell types were completely negative for Factor VIII-related antigen immunofluorescence; $95 \%$ of endothelial cells were brightly positive. In summary, the IMCD and PT cells were highly purified and did not contain significant interstitial, fibroblast, macrophage, mesangial, or endothelial cell contamination.

NO $0^{\bullet}$ production by inner medullary collecting duct cells. Unstimulated IMCD cells produced total $\mathrm{NO}_{2}^{-} / \mathrm{NO}_{3}^{-}$at levels near the threshold for detection $(7 \pm 3 \mathrm{nmol} / \mathrm{mg}$ protein). Addition of $150 \mathrm{U} / \mathrm{ml} \mathrm{TNF}-\alpha+500 \mathrm{U} / \mathrm{ml} \mathrm{IFN}-\gamma$ for $96 \mathrm{~h}$ markedly increased total $\mathrm{NO}_{2}^{-} / \mathrm{NO}_{3}^{-}$accumulation in the supernatants (52 $\pm 4 \mathrm{nmol} / \mathrm{mg}$ protein, $P<0.0001$ vs. control) (Fig. 1). LNMMA $(0.5 \mathrm{mM})$ inhibited the stimulatory effect of TNF- $\alpha$ and IFN- $\gamma(5 \pm 2 \mathrm{nmol} / \mathrm{mg}$ protein $)$. Finally, the addition of 5 $\mathrm{mM}$ L-arginine partially reversed the inhibitory effect of $\mathrm{L}$ -

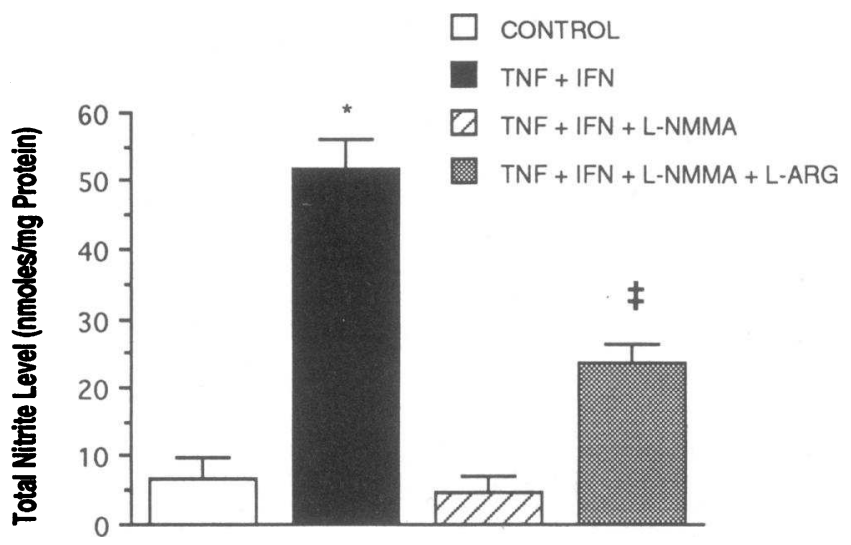

Figure 1. Total nitrite $\left(\mathrm{NO}_{2}^{-} / \mathrm{NO}_{3}^{-}\right)$production by IMCD cells. Total nitrite was measured in the supernatants of rat IMCD cells after 96 $\mathrm{h}$ of incubation with the reagents noted in the figure. TNF, $150 \mathrm{U} / \mathrm{ml}$ TNF- $\alpha$; IFN, 500 U/ml IFN- $\gamma$; L-NMMA, 0.5 mM L-NMMA; LARG, $5 \mathrm{mM}$ L-arginine $\left(n=8\right.$ in each group; ${ }^{*} P<0.0001$ vs control; ${ }^{\ddagger} P<0.001$ vs control).

NMMA on TNF- $\alpha$ and IFN- $\gamma$-stimulated NO ${ }^{\bullet}$ production (Fig. 1).

TNF- $\alpha$ augmented $\mathrm{NO}^{\circ}$ production in a dose-dependent manner. Raising the TNF- $\alpha$ dose from $150 \mathrm{U} / \mathrm{ml}$ to $300 \mathrm{U} / \mathrm{ml}$ (keeping the IFN- $\gamma$ dose constant at $500 \mathrm{U} / \mathrm{ml}$ ) increased $\mathrm{NO}_{2}^{-} /$ $\mathrm{NO}_{3}^{-}$concentration from $118 \pm 7$ to $158 \pm 12 \mu \mathrm{M} / \mathrm{mg}$ protein $(P$ $<0.03$ ) (Fig. $2 a$ ). In addition, TNF- $\alpha$ and IFN- $\gamma$ stimulated $\mathrm{NO}^{\circ}$ production by IMCD cells in a time-dependent manner. $\mathrm{NO}_{2}^{-}$was not detected in the supernatants after $48 \mathrm{~h}$ of exposure to these cytokines. $72 \mathrm{~h}$ of incubation with TNF- $\alpha$ and IFN- $\gamma$ increased total $\mathrm{NO}_{2}^{-} / \mathrm{NO}_{3}^{-}$to $23 \pm 5 \mathrm{nmol} / \mathrm{mg}$ protein; 96 $\mathrm{h}$ of exposure further augmented total $\mathrm{NO}_{2}^{-} / \mathrm{NO}_{3}^{-}$accumulatión $(52 \pm 4 \mathrm{nmol} / \mathrm{mg}$ protein, $P<0.0006)$ (Fig. $2 \mathrm{~b})$. At $96 \mathrm{~h}$, $75 \%$ of total $\mathrm{NO}_{2}^{-} / \mathrm{NO}_{3}^{-}$was $\mathrm{NO}_{3}^{-}$and $25 \%$ was $\mathrm{NO}_{2}^{-}$.

$N O^{\circ}$ production by proximal tubular cells. PT cells also synthesized $\mathrm{NO}^{\circ}$ in response to cytokine stimulation. There were no detectable breakdown products of $\mathrm{NO}^{\circ}$ in the supernatants of unstimulated cells, while cell exposed to $150 \mathrm{U} / \mathrm{ml} \mathrm{TNF}-\alpha$ and $500 \mathrm{U} / \mathrm{ml}$ IFN- $\gamma$ had a total $\mathrm{NO}_{2}^{-} / \mathrm{NO}_{3}^{-}$concentration of $164 \pm 10 \mathrm{nmol} / \mathrm{mg}$ protein $(P<0.0001$ vs. control $)$. Concurrent exposure to $0.5 \mathrm{mM}$ L-NMMA inhibited TNF- $\alpha$ and IFN- $\gamma-$ stimulated production of $\mathrm{NO}^{\circ}$. The inhibitory effect of $\mathrm{L}$ NMMA could be partially overcome by addition of $5 \mathrm{mM} \mathrm{L-ar-}$ ginine (Fig. 3). In this cell population as well, $\mathrm{NO}^{\circ}$ was preferentially broken down to $\mathrm{NO}_{3}^{-}(90 \%)$ rather than $\mathrm{NO}_{2}^{-}(10 \%)$.

$N O S_{i} m R N A$. Traditional Northern analysis and RNAase protection assays were not sensitive enough to detect NOS mRNA under unstimulated conditions, hence a quantitative PCR method was used. The accuracy of the quantitative PCR used was determined as previously described by this laboratory (39). In the first control, the reproducibility of reverse transcription was examined. Three separate reverse transcriptions of the same RNA sample, followed by PCR of the resultant cDNA (using the same NOS $_{\mathrm{i}}$ and $\beta$-actin standard curves), yielded $<6 \%$ variability in measured NOS $_{i}$ and $\beta$-actin $c D N A$; the ratio of $\operatorname{NOS}_{i}$ to $\beta$-actin cDNA varied by $<7 \%$. In the second control, the reproducibility of quantitation of cDNA was evaluated. Three separate PCR amplifications, each using independently made standard curves, were performed on the same sample of cDNA. The calculated amount of $\operatorname{NOS}_{i}$ and 


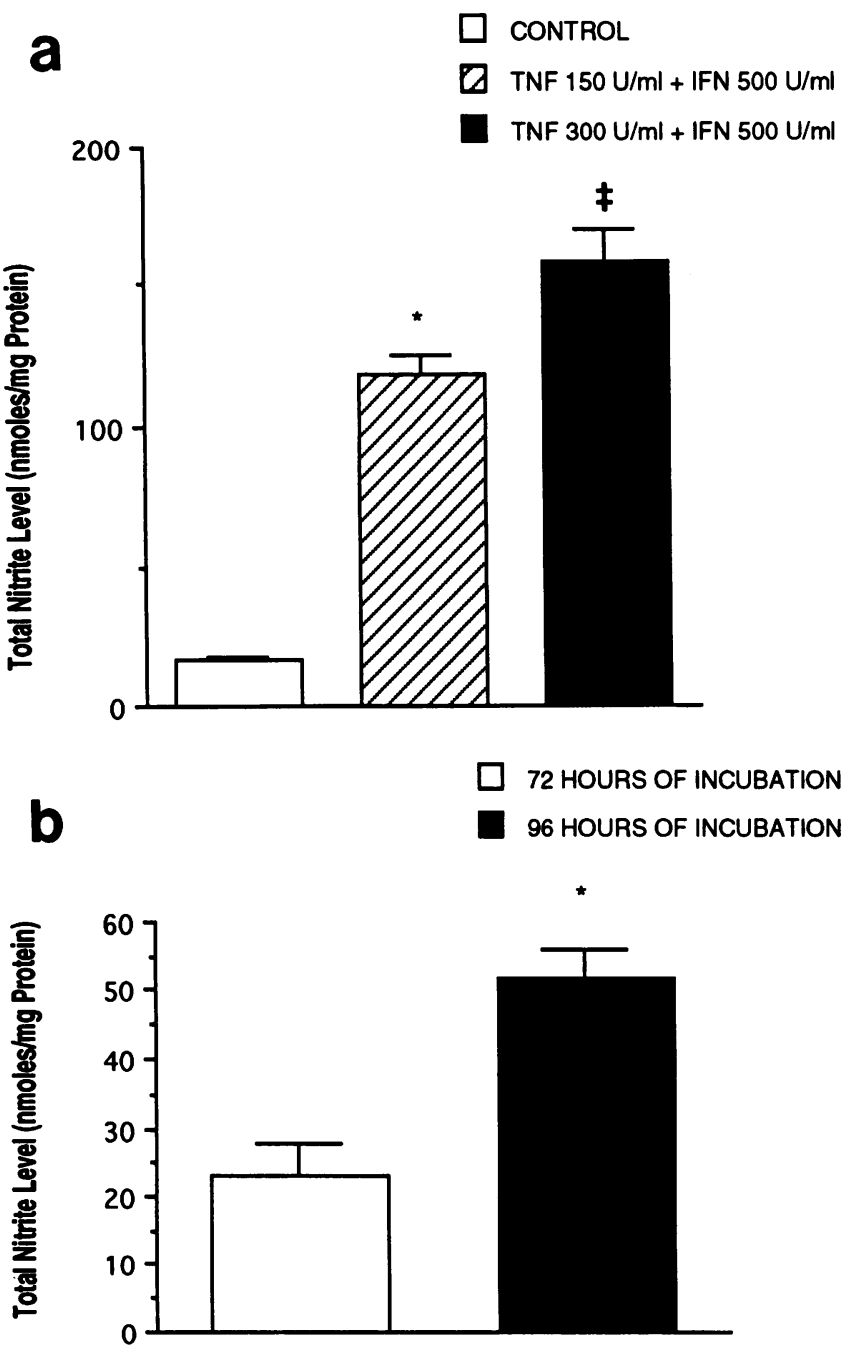

Figure 2. (a) Effect of TNF- $\alpha$ dose on total nitrite production $\left(\mathrm{NO}_{2}^{-} /\right.$ $\mathrm{NO}_{3}^{-}$) by IMCD cells. Total nitrite was measured in the supernatants of rat IMCD cells after $96 \mathrm{~h}$ of incubation with increasing doses of TNF- $\alpha\left(n=4\right.$ in each group; ${ }^{*} P<0.0001$ vs control; ${ }^{\ddagger} P<0.03$ vs $150 \mathrm{U} / \mathrm{ml}$ of TNF- $\alpha$ ). (b) Effect of time on total nitrite production $\left(\mathrm{NO}_{2}^{-} / \mathrm{NO}_{3}^{-}\right)$by IMCD cells. Total nitrite was measured in the supernatants of rat IMCD cells after 72 and $96 \mathrm{~h}$ of incubation with 150 $\mathrm{U} / \mathrm{ml}$ of TNF- $\alpha$ and $500 \mathrm{U} / \mathrm{ml}$ of IFN- $\gamma\left(n=8\right.$ in each group; ${ }^{*} P$ $<0.0006$ vs 72 h).

$\beta$-actin cDNA each varied by $<16 \%$; while the ratio of NOS to $\beta$-actin cDNA varied by $<12 \%$. Standard curves using $0.1-100$ pg of $\beta$-actin cDNA (which encompasses all sample values) gave correlation coefficients invariably $>0.99$. Similarly, standard curves using $0.1-100 \mathrm{fg}$ of NOS $\mathrm{CDNA}_{\mathrm{i}}$ (which encompasses all sample values) gave correlation coefficients invariably $>0.97$. Finally, PCR of identically processed samples but without reverse transcriptase, or PCR in which water was substituted for CDNA, yielded no detectable product.

The results of reverse transcription and polymerase chain reaction of RNA from PT and IMCD cells are shown in Fig. 4. Unstimulated PT and IMCD cells contained extremely low levels of NOS ${ }_{\mathrm{i}}$ mRNA (both cell types had a ratio of NOS $: \beta$ actin of 1:27,000). Addition of $150 \mathrm{U} / \mathrm{ml} \mathrm{TNF}-\alpha+500 \mathrm{U} / \mathrm{ml}$ IFN- $\gamma$ for $96 \mathrm{~h}$ resulted in a marked stimulation of PT and

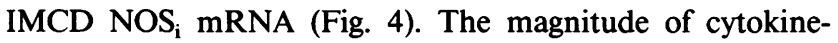
stimulated NOS $_{\mathrm{i}}$ mRNA appears to be greater in IMCD cells

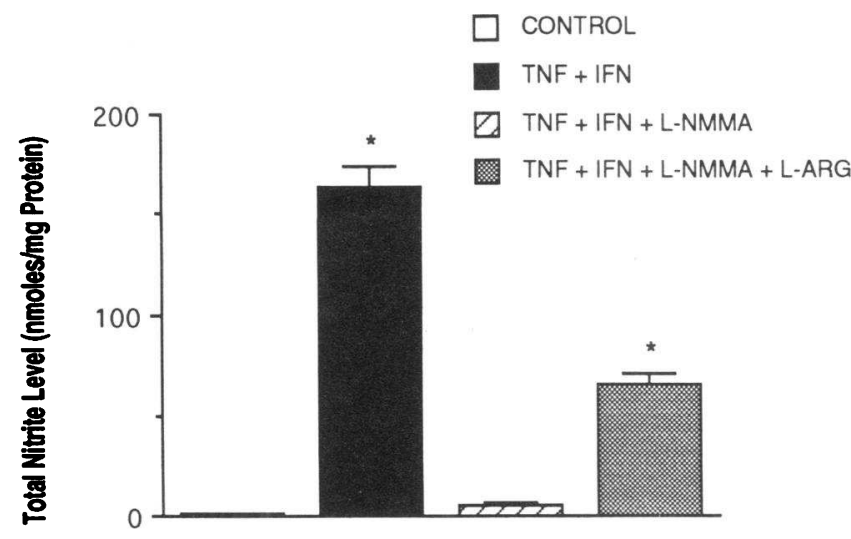

Figure 3. Total nitrite production $\left(\mathrm{NO}_{2}^{-} / \mathrm{NO}_{3}^{-}\right)$by PT cells. Total nitrite was measured in the supernatants of rat PT cells after $96 \mathrm{~h}$ of incubation with the reagents noted in the figure. TNF, $150 \mathrm{U} / \mathrm{ml}$ of TNF- $\alpha$; IFN, $500 \mathrm{U} / \mathrm{ml}$ of IFN- $\gamma$; L-NMMA, $0.5 \mathrm{mM}$ L-NMMA; L-ARG, $5 \mathrm{mM}$ L-arginine ( $n=7$ or 8 for each group; ${ }^{*} P<0.0001$ vs control).

than in PT cells. However, given that the levels of total $\mathrm{NO}_{2}^{-} /$ $\mathrm{NO}_{3}^{-}$appeared to be greater in the supernatants of PT than in IMCD cells, the significance of higher cytokine-induced NOS $_{i}$ mRNA levels in IMCD cells is unclear. The increase in NOS $/$ $\beta$-actin mRNA ratio after cytokine exposure was not due to a decrease in $\beta$-actin mRNA: PT $\beta$-actin mRNA was $38 \pm 25 \mathrm{pg}$ in unstimulated cells and $73 \pm 34 \mathrm{pg}$ in TNF- $\alpha$ and IFN- $\gamma$ treated cells; while IMCD $\beta$-actin mRNA was $1.2 \mathrm{pg} \pm 0.2 \mathrm{pg}$ in unstimulated cells and $1.4 \pm 0.6 \mathrm{pg}$ in TNF- $\alpha$ and IFN- $\gamma$ treated cells.

\section{Discussion}

This study demonstrates that PT and IMCD cells stimulated with TNF- $\alpha$ and IFN- $\gamma$ produce large amounts of NO'. LNMMA, an inhibitor of both L-arginine transport and NOS activity (40), blocks $\mathrm{NO}^{\circ}$ production in cytokine-stimulated epithelial cells. Excess L-arginine partially reverses this inhibition. Finally, cytokine treatment of these cells markedly increases NOS $_{\mathrm{i}}$ mRNA levels, confirming that these cells can express $\mathrm{NOS}_{\mathrm{i}}$ and may serve as a source for the increased $\mathrm{NO}^{\circ}$ generation caused by inflammatory mediators.

$\mathrm{NO}_{2}^{-}$levels were not detectable in the supernatants of renal

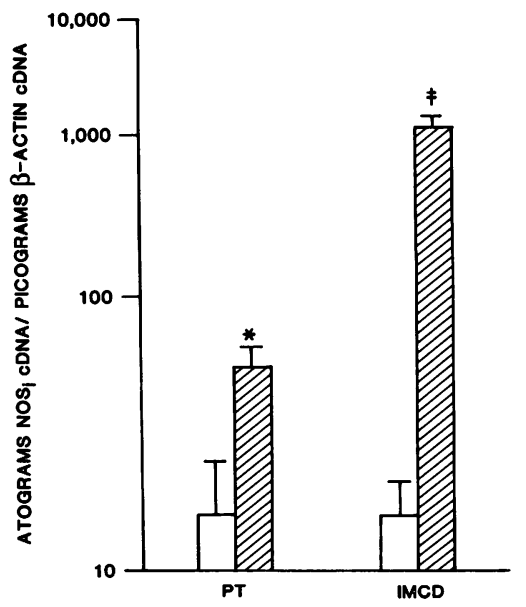

Figure 4. Inducible $\mathrm{NOS}_{\mathrm{i}}$ mRNA levels in IMCD and PT cells. $\mathrm{NOS}_{\mathrm{i}}$ mRNA was measured in PT and IMCD cells $96 \mathrm{~h}$ after incubation in media alone (open bar) and after stimulation with 150 $\mathrm{U} / \mathrm{ml}$ of TNF- $\alpha$ and 500 $\mathrm{U} / \mathrm{ml}$ of IFN- $\gamma$ (crosshatched bar $)$. $(n=3$ for each data point; ${ }^{*} P$ $<0.05$ vs control; ${ }^{\ddagger} P$ $<0.005$ vs control). 
epithelial cells exposed to TNF- $\alpha$ and IFN- $\gamma$ for $48 \mathrm{~h}$. In contrast, TNF- $\alpha$ induction of NOS activity in bovine endothelial cells occurs after $8 \mathrm{~h}(41)$. This previous study used a more sensitive assay of $\mathrm{NO}^{\circ}$ detection; if such a method had been used in the current study, induction of renal epithelial cell $\mathrm{NO}^{\circ}$ synthesis may have been observed at an earlier time. While delineation of the time of onset of cytokine-stimulated $\mathrm{NO}^{\circ}$ production by renal tubule cells is of interest, the current study focused on the time required to produce micromolar amounts of $\mathrm{NO}^{\circ}$ in the culture supernatant. This amount of $\mathrm{NO}^{\circ}$ clearly separates constitutive from inducible production and underscores the potential physiologic differences between the two systems.

IMCD cells appeared to have a higher $\mathrm{NOS}_{\mathrm{i}} / \beta$-actin mRNA ratio, however, PT cells appeared to produce more $\mathrm{NO}^{\circ}$. Since, due to logistic considerations, IMCD and PT cells were not obtained from the same rats, direct comparison of $\mathrm{NOS}_{\mathrm{i}}$ activity between the two cell types was not possible. While precise determination of the relative activity of $\mathrm{NOS}_{\mathrm{i}}$ in nephron segments would be of interest, the present study was not designed to address this issue. Rather, two renal tubule cell types were chosen that had the greatest difference in baseline arginine synthesis: synthesis of arginine by the unstimulated rat nephron is almost entirely limited to the PT, while the IMCD produces virtually no detectable arginine (42). Despite differences in baseline arginine synthesis, PT and IMCD cells could both be induced to express NOS $_{i}$ and generate substantial amounts of $\mathrm{NO}^{\circ}$. Hence, it appears that once IMCD cells are stimulated, ample arginine precursors are available. The source of this arginine has yet to be determined, but likely reflects an increase in arginine uptake and/or upregulation of arginine synthetic ability. It should be noted that the absolute level of $\mathrm{NO}^{\circ}$ produced by a tubule cell may not solely determine the magnitude of the local response. The renal medulla, for example, has been shown to produce more cGMP in response to $\mathrm{NO}^{\circ}$ than does the renal cortex (43). The amount of $\mathrm{NO}^{\circ}$ produced by cytokine stimulated PT and IMCD cells is similar to that reported for IL-1-stimulated rat aortic smooth muscle cells (19), but less than can be produced by murine peritoneal macrophages which can generate $\sim 1.5 \mu \mathrm{mol} / \mathrm{mg}$ protein per $20 \mathrm{~h}(44)$.

NOS $_{\mathrm{c}}$ has been demonstrated in LCC-PK, , a porcine proximal tubule-like cell line $(9,10)$. The $\mathrm{NO}^{\circ}$ produced by the constitutive enzyme is believed to function as an intra- and extracellular messenger by activating soluble guanylate cyclase (10). In the tubular epithelial cell, $\mathrm{NO}^{\circ}$ has also been proposed to have a regulatory role in sodium absorption $(10,43)$. The inducible isoform of NOS, however, has not been previously shown to exist in kidney epithelial cells. The NOS $_{\mathrm{i}}$ requires L-arginine or an L-arginine containing compound as a substrate and is dependent on NADPH, tetrahydrobiopterin, flavin adenine dinucleotide, and flavin mononucleotide; a strict requirement for calcium has not been demonstrated (11). The inducible L-arginine: $\mathrm{NO}^{\bullet}$ pathway appears to be involved in defense against intracellular microorganisms, activation of cytotoxic macrophages, and the hypotension induced by endotoxin (14, 40,45 ). Whether inducible $\mathrm{NO}^{\circ}$ production by renal tubular epithelial cells affects renal vascular tone, sodium absorption, or resistance to cancer cells or infection remains to be determined.

In addition to a possible physiologic role, inducible $\mathrm{NO}^{\circ}$ production may play a role in renal pathophysiology. Cells stimulated to generate $\mathrm{NO}^{\circ}$ may themselves be injured by this reactive species because it can inhibit key iron containing enzymes involved in the citric acid cycle, mitochondrial respiration, and DNA synthesis (33). Experimental studies suggest that $\mathrm{NO}^{\circ}$ may partly mediate immune complex induced tissue injury. Inhibiting $\mathrm{NO}^{\bullet}$ generation, for example, prevents the development in rats of immune complex alveolitis and dermal vasculitis (46). An NOS inhibitor also suppresses adjuvant induced arthritis in rats (47). Glomerular NO production, presumably arising from macrophages, is enhanced in immune complex glomerulonephritis, raising the possibility of a role for $\mathrm{NO}^{\circ}$ in producing or modulating the injury (48). Our results suggest that renal tubule epithelial cells may also be an important source of $\mathrm{NO}^{\circ}$ in the setting of inflammatory renal diseases. In addition, renal tubule $\mathrm{NO}^{\bullet}$ generation may contribute to the pathophysiology of other renal diseases characterized by tubule damage, such as acute tubular necrosis.

Other epithelial cells may contain the inducible isoform of NOS. EMT-6 cells, a murine mammary adenocarcinoma, produce micromolar amounts of nitrite and nitrate after cytokine stimulation (21). In addition, cultured hepatocytes obtained from rats injected with Corynebacterium parvum generate $\sim 400 \mathrm{nmol}$ nitrate and nitrate/mg protein per $24 \mathrm{~h}$. This nitrate and nitrite production were calcium independent, indicative of $\mathrm{NOS}_{\mathrm{i}}$-mediated production of $\mathrm{NO}^{\circ}(17)$. Finally, insulin-producing HIT cells release $\mathrm{NO}^{\circ}$ and express NOS $_{\mathrm{i}}$ mRNA after exposure to interleukin-1 (49).

In summary, we have demonstrated the presence of inducible nitric oxide synthase and inducible $\mathrm{NO}^{\circ}$ production in proximal tubule and inner medullary collecting duct cells. To our knowledge, this is the first report of inducible $\mathrm{NO}^{\circ}$ production in renal epithelial cells. The role of this pathway in the physiology and pathophysiology of kidney function remains to be determined.

\section{Acknowledgments}

The authors thank Eva Padilla and Alisa Hughes for their technical assistance.

This research was supported by Department of Veterans Affairs Medical Research Funds, a Department of Veterans Affairs Career Development Award, and National Institute of Diabetes and Digestive and Kidney Diseases grant R29 DK44440-01 to D. E. Kohan and a Research Career Development Award NIH 5 K04 HL-02297-04 to J. R. Michael. Dr. Markewitz was supported by National Institutes of Health Training Grant NIH 5 T32 HL07636-04.

\section{References}

1. Romero, J. C., V. Lahera, M. G. Salom, and M. L. Biondi. 1992. Role of the endothelium-dependent relaxing factor nitric oxide on renal function. J. Am. Soc. Nephrol. 2:1371-1387.

2. Lahera, V., M. G. Salom, M. J. Fiksen-Olsen, L. Raij, and J. C. Romero. 1990. Effects of $\mathrm{N}^{\mathrm{G}}$-monomethyl-L-arginine and L-arginine on acetylcholine renal response. Hypertension (Dallas). 15:659-663.

3. Lahera, V., M. G. Salom, M. J. Fiksen-Olsen, and J. C. Romero. 1991. Mediatory role of endothelium-derived nitric oxide in renal vasodilatory and excretory effects of bradykinin. Am. J. Hypertens. 4:260-262.

4. Vidal, M. J., J. C. Romero, and P. M. Vanhoutte. 1988. Endotheliumderived relaxing factor inhibits renin release. Eur. J. Pharmacol. 149:401-402.

5. Ercan, Z. S., A. S. Soydan, and R. K. Türker. 1990. Possible involvement of endothelium in the responses of various vasoactive agents in rabbit isolated perfused kidney. Gen. Pharmacol. 21:205-209.

6. Ito, S., C. S. Johnson, and O. A. Carretero. 1991. Modulation of angiotensin II-induced vasoconstriction by endothelium-derived relaxing factor in the isolated microperfused rabbit afferent arteriole. J. Clin. Invest. 87:1656-1663.

7. Lahera, V., M. G. Salom, F. Miranda-Guardiola, S. Moncada, and J. C. Romero. 1991. Effects of $\mathrm{N}^{\mathrm{G}}$-nitro-L-arginine methyl ester on renal function and blood pressure. Am. J. Physiol. 261:F1033-F1037. 
8. Stoos, B. A., O. A. Carretero, R. D. Farhy, G. Scicli, and J. L. Garvin. 1992. Endothelium-derived relaxing factor inhibits transport and increases cGMP content in cultured mouse cortical collecting duct cells. J. Clin. Invest. 89:761-765.

9. Ishii, K., L. D. Gorsky, U. Förstermann, and F. Murad. 1989. Endothelium-derived relaxing factor (EDRF): the endogenous activator of soluble guanylate cyclase in various types of cells. J. Appl. Cardiol. 4:505-512.

10. Ishii, K., B. Chang, J. F. Kerwin, Jr., F. L. Wagenaar, Z.-J. Huang, and F. Murad. 1991. Formation of endothelium-derived relaxing factor in porcine kidney epithelial LLC-PK 1 cells: an intra- and intercellular messenger for activation of soluble guanylate cyclase. J. Pharmacol. Exp. Ther. 256:38-43.

11. Stuehr, D. J., and O. W. Griffith. 1992. Mammalian nitric oxide synthases. Adv. Enzymol. Relat. Areas Mol. Biol. 65:287-346.

12. Stuehr, D. J., and M. A. Marletta. 1985. Mammalian nitrate biosynthesis: mouse macrophages produce nitrite and nitrate in response to Escherichia coli lipopolysaccharide. Proc. Natl. Acad. Sci. USA. 82:7738-7742.

13. Hibbs, J. B., Jr., R. R. Taintor, and Z. Vavrin. 1987. Macrophage cytotoxicity: role for L-arginine deiminase and imino nitrogen oxidation to nitrite. Science (Wash. DC). 235:473-476.

14. Kilbourn, R. G., and P. Belloni. 1990. Endothelial cell production of nitrogen oxides in response to interferon $\gamma$ in combination with tumor necrosis factor, interleukin-1, or endotoxin. J. Natl. Cancer Inst. 82:772-776.

15. Billiar, T. R., R. D. Curran, D. J. Stuehr, M. A. West, B. G. Bentz, and R. L. Simmons. 1989. An L-arginine-dependent mechanism mediates Kupffer cell inhibition of hepatocyte protein synthesis in vitro. J. Exp. Med. 169:14671472.

16. Curran, R. D., T. R. Billiar, D. J. Stuehr, K. Hofmann, and R. L. Simmons. 1989. Hepatocytes produce nitrogen oxides from $L$-arginine in response to inflammatory products of Kupffer cells. J. Exp. Med. 170:1769-1774.

17. Billiar, T. R., R. D. Curran, D. J. Stuehr, J. Stadler, R. L. Simmons, and S. A. Murray. 1990. Inducible cytosolic enzyme activity for the production of nitrogen oxides from L-arginine in hepatocytes. Biochem. Biophys. Res. Commun. 168:1034-1040.

18. Marsden, P. A., and B. J. Ballermann. 1990. Tumor necrosis factor $a$ activates soluble guanylate cyclase in bovine glomerular mesangial cells via an L-arginine-dependent mechanism. J. Exp. Med. 172:1843-1852.

19. Beasley, D., J. H. Schwartz, and B. M. Brenner. 1991. Interleukin 1 in duces prolonged L-arginine-dependent cyclic guanosine monophosphate and nitrite production in rat vascular smooth muscle cells. J. Clin. Invest. 87:602-608.

20. Werner-Felmayer, G., E. R. Werner, D. Fuchs, A. Hausen, G. Reibnegger, and H. Wachter. 1990. Tetrahydrobiopterin-dependent formation of nitrite and nitrate in murine fibroblasts. J. Exp. Med. 172:1599-1607.

21. Amber, I. J., J. B. Hibbs, Jr., R. R. Taintor, and Z. Vavrin. 1988. Cytokines induce an L-arginine-dependent effector system in nonmacrophage cells. $J$. Leukocyte Biol. 44:58-65.

22. Stuehr, D. J., and M. A. Marletta. 1987. Induction of nitrite/nitrate synthesis in murine macrophages by BCG infection, lymphokines, or interferon- $\gamma . J$. Immunol. 139:518-525.

23. Grenier, F. C., and W. L. Smith. 1978. Formation of 6-Keto-PGF ${ }_{1 \alpha}$ by collecting tubule cells isolated from rabbit renal papillae. Prostaglandins. 16:759772.

24. Grenier, F. C., T. E. Rollins, and W. L. Smith. 1981. Kinin-induced prostaglandin synthesis by renal papillary collecting tubule cells in culture. $\mathrm{Am}$. J. Physiol. 241:F94-F104.

25. Kohan, D. E. 1989. Interleukin-1 regulation of prostaglandin $\mathrm{E}_{2}$ synthesis by the papillary collecting duct. J. Lab. Clin. Med. 114:717-723.

26. Kohan, D. E., A. K. Hughes, and S. L. Perkins. 1992. Characterization of endothelin receptors in the inner medullary collecting duct of the rat. J. Biol Chem. 267:12,336-12,340.

27. Kohan, D. E., and F. T. Fiedorek, Jr. 1991. Endothelin synthesis by rat inner medullary collecting duct cells. J. Am. Soc. Nephrol. 2:150-155.

28. Vinay, P., A. Gougoux, and G. Lemieux. 1981. Isolation of a pure suspension of rat proximal tubules. Am. J. Physiol. 241:F403-F411.

29. Rovin, B. H., E. Wurst, and D. E. Kohan. 1990. Production of reactive oxygen species by tubular epithelial cells in culture. Kidney Int. 37:1509-1514.
30. Kohan, D. E. 1991. Endothelin synthesis by rabbit renal tubule cells. Am. J. Physiol. 261:F221-F226.

31. Ding, A. H., C. F. Nathan, and D. J. Stuehr. 1988. Release of reactive nitrogen intermediates and reactive oxygen intermediates from mouse peritoneal macrophages: comparison of activating cytokines and evidence for independent production. J. Immunol. 141:2407-2412.

32. Marletta, M. A., P. S. Yoon, R. Iyengar, C. D. Leaf, and J. S. Wishnok. 1988. Macrophage oxidation of L-arginine to nitrite and nitrate: nitric oxide is an intermediate. Biochemistry. 27:8706-8711.

33. Drapier, J.-C., and J. B. Hibbs, Jr. 1988. Differentiation of murine macrophages to express nonspecific cytotoxicity for tumor cells results in L-arginine dependent inhibition of mitochondrial iron-sulfur enzymes in the macrophage effector cells. J. Immunol. 140:2829-2838.

34. Green, L. C., D. A. Wagner, J. Glogowski, P. L. Skipper, J. S. Wishnok, and S. R. Tannenbaum. 1982. Analysis of nitrate, nitrite, and $\left[{ }^{15} \mathrm{~N}\right]$ nitrate in biological fluids. Anal. Biochem. 126:131-138.

35. Bartholomew, B. 1984. A rapid method for the assay of nitrate in urine using the nitrate reductase enzyme of Escherichia coli. Fd. Chem. Toxic. 22:541543.

36. Goldschmidt, R. C., and H. K. Kimelberg. 1989. Protein analysis of mammalian cells in monolayer culture using the bicinchoninic assay. Anal. Biochem 177:41-45.

37. Lyons, C. R., G. J. Orloff, and J. M. Cunningham. 1992. Molecular cloning and functional expression of an inducible nitric oxide synthase from a murine macrophage cell line. J. Biol. Chem. 267:6370-6374.

38. Bredt, D. S., P. M. Hwang, C. E. Glatt, C. Lowenstein, R. R. Reed, and S. H. Snyder. 1991. Cloned and expressed nitric oxide synthase structurally resembles cytochrome P-450 reductase. Nature (Lond.). 351:714-718.

39. Hughes, A. K., R. C. Cline, and D. E. Kohan. 1992. Alterations in renal endothelin-1 production in the spontaneously hypertensive rat. Hypertension (Dallas). 20:666-673.

40. Hibbs, J. B., Jr., Z. Vavrin, and R. R. Taintor. 1987. L-arginine is required for expression of the activated macrophage effector mechanism causing selective metabolic inhibition in target cells. J. Immunol. 138:550-565.

41. Lamas, S., T. Michel, B. M. Brenner, and P. A. Marsden. 1991. Nitric oxide synthesis in endothelial cells: evidence for a pathway inducible by TNF- $\alpha$. Am. J. Physiol. 261:C634-C641.

42. Levillain, O., A. Hus-Citharel, F. Morel, and L. Bankir. 1990. Localization of arginine synthesis along rat nephron. Am. J. Physiol. 259:F916-F923.

43. Biondi, M. L., R. J. Bolterman, and J. C. Romero. 1992. Zonal changes of guanidine $3^{\prime}, 5^{\prime}$-cyclic monophosphate related to endothelium-derived relaxing factor in dog renal medulla. Renal Physiol. Biochem. 15:16-22.

44. Granger, D. L., J. B. Hibbs, Jr., J. R. Perfect, and D. T. Durack. 1990. Metabolic fate of L-arginine in relation to microbiostatic capability of murine macrophages. J. Clin. Invest. 85:264-273.

45. Denis, M. 1991. Tumor necrosis factor and granulocyte macrophagecolony stimulating factor stimulate human macrophages to restrict growth of virulent Mycobacterium avium and to kill avirulent $M$. avium: killing effector mechanism depends on the generation of reactive nitrogen intermediates. $J$. Leu kocyte Biol. 49:380-387.

46. Mulligan, M. S., J. M. Hevel, M. A. Marletta, and P. A. Ward. 1991 Tissue injury caused by deposition of immune complexes is L-arginine dependent. Proc. Natl. Acad. Sci. USA. 88:6338-6342.

47. Ialenti, A., and M. Di Rosa. 1991. Modulation of adjuvant arthritis by endogenous nitric oxide. In Biology of Nitric Oxide: Second International Meeting. S. Moncada, M. A. Marletta, and J. B. Hibbs, Jr., editors. IBC Technical Services Ltd., London. Poster 132. Abstract.

48. Cook, H. T., and R. Sullivan. 1991. Glomerular nitrite synthesis in in situ immune complex glomerulonephritis in the rat. Am. J. Pathol. 139:1047-1052.

49. Eizirik, D. L., E. Cagliero, A. Bjorklund, and N. Welsh. 1992. Interleukin1 beta induces the expression of an isoform of nitric oxide synthase in insulin-producing cells, which is similar to that observed in activated macrophages. FEBS (Fed. Eur. Biochem. Soc.) Lett. 308:249-252. 